\title{
Biblical Studies on Holiday? A Personal View of Reception History
}

\author{
Susan Gillingham \\ University of Oxford
}

\section{The holiday metaphor}

I recently heard 'reception history' referred to as 'biblical studies on holiday'. I am not sure who originally said this, but it seems to me that such an observation is an ideal way to start to reflect on reception history as a relatively new arrival to the discipline of biblical studies. I do not think this was how it was intended, but it could of course be a commendation rather than criticism. Let me start with this way of reading it, anyway.

Much, of course, depends on how one sees a 'holiday'. For someone who loves travel, 'holiday' is what makes sense of the rest of life. You begin to gain a total change of perspective through encountering a new culture, a new language, a different history. Gradually you acquire a different set of priorities: things which really mattered 'back there' seem to be not quite as urgent or pressing as you have time to focus on different opportunities - perhaps in art, or music or literature. And you can return with new projects which might complement the older, more familiar ones.

So the metaphor of a 'holiday' might work well in defining reception history in relation to biblical studies. It offers a change of perspective because its encounter with so many cultures through time and space means that the framework of interpretation is much broader. It certainly provides a challenge to a traditional set of priorities which has evolved in historical and literary studies of the Bible over the last two centuries. And it also offers new projects to biblical studies, not least in bringing in other humanities disciplines such as music, art and literature, and cultural and ecclesiastical history. So the 'holiday' metaphor is a good one. In fact reception history could be one of the best travel guides biblical studies could use. 


\section{Defining biblical studies}

If much depends upon how one sees a holiday, much also depends on how one sees biblical studies. My own perspective is that biblical studies, as an academic discipline, has really gone through the mill since I studied it as an undergraduate in the late 1960s and early 1970s. When I started, there was still some confidence about what we were doing and how it might produce some assured results: Gerhard von Rad's Theology of the Old Testament and Martin Noth's theory of the amphictyony could still be cited without too much apology. But by the time I had finished it was clear that several new methodological questions were being asked, for which there were no clear answers. I remember how, throughout the 1970s, historical criticism underwent enormous fragmentation, so that one was never really clear whether one should read a biblical text by first applying textual criticism, or form criticism, or source criticism, or tradition criticism, or redaction criticism or, later still, canon criticism. At that time biblical studies seemed to me to be rather like a huge department store, where it became increasingly difficult to know which 'floor' of critical enquiry one should start with first. My own interests were in tradition criticism, and I did my MA thesis on assessing Wolfhart Pannenberg's theory that Old Testament History comprised in the main 'the history of the transmission of traditions' So to follow the analogy of the department store I suppose at that time I started near the top floor first.

But by the late 1970s and early 1980s new emphases were coming to the fore. Partly as a result of the questions asked by, for example, feminist interpreters and social scientists and liberation theologians, rhetorical criticism, in its various forms, both theoretical and more pragmatic, became a crucial methodology for asking about the meaning of the text: this took the emphasis away from initial questions about the 'text in context' to questions about the 'reader in context'. By the mid-1980s this gave rise to a whole range of other methodological approaches, not least a fresh understanding of the Bible as literature - not just as good ancient literature, but as literature capable of being understood by the use of more contemporary literary techniques which could be applied both to biblical prose and to biblical poetry. This huge variety of methodological approaches to biblical studies has multiplied and fragmented up to the present day. And depending on what you say and how you say it you can so easily get pigeon-holed; I have been called everything from a post-modernist to a covert evangelical.

This autobiographical account of biblical studies has been interpreted only through the eyes of the 'academy'. If we added to this a version of biblical studies as understood in the church or the synagogue, or through the non-specialist secular judgements of the media, it would become even more difficult to define precisely what 'biblical studies' is and does. If I were being very pessimistic, I might argue that biblical studies could certainly do with a holiday; it needs fresh perspectives, a reassessment of its priorities and a consideration of new projects. 


\section{Defining reception history}

Whether we perceive reception history positively or negatively is closely related to our perception of biblical studies; whether we define the latter discipline according to those particular methodologies which 'work' for us, or whether we have a sufficiently open view of it to include approaches other than those we usually espouse. So there are some who see reception history as escapism, lacking 'rigour' in the way they would define that term in their own specialism, and there are others who view reception history as an inevitable consequence of the last forty years' evolution within the discipline and so welcome its presence. It is clear that I belong to the latter category. I see it as very much part of the academy of biblical studies rather than an unwelcome intruder. I would claim this on two counts.

First, I would argue that it is reception history. Some aspects of it are closely related to the historical concerns of biblical studies. To use an analogy of an archaeological dig, reception history allows us to see there are many more levels in our historical understanding of the text than the purportedly 'top' level which in the 1980s I might have labelled as 'canon criticism'. Because it is interested in cultural history and the influence of a particular text in a particular culture, 'history of culture' is a vitally important dimension which is added on to the more traditional understanding of the 'history of the text'. Reception history encourages a dialogue between these two elements: what holds this dialogue together is a perspective which is historical. Some scholars work from the reception of text in a particular period of history backwards to the earlier history of the text in its biblical setting; others work from the history of the text in its biblical setting forwards to the reception of the text in a cultural setting. I usually do the latter. The sort of specifically textual work I do, focussing on individual psalms, means it is actually easier for me to start as far back as possible, with the text in its ancient context and then move forwards, chronologically speaking. ${ }^{1}$ So (again using the analogy of the archaeological dig) another significant level would be the reception of the text in its early translation; a further level would involve assessing the occurrences of the psalm in the literature of the Second Temple Period (including of course, where relevant, Qumran); and other levels, further and further upwards, would be the consideration of later Jewish interpretations through Midrashim and the Targums and later Christian reconstructions through the Church Fathers and the Glosses. So this is the historical approach with a much broader remit; even though precise answers cannot be given, continual questions have to be asked about the origins not just about the text in its ancient setting but about the text in the cultural

1 By this I am not implying that the closer to the 'original' one attempts to work, the closer to the 'truth' one gets. Mine is more to do with a practical methodological process; it is easier to start at the beginning of a story than to take it up halfway through. 
settings of later interpreters. ${ }^{2}$ Discerning the levels in the text this way applies mainly to the more exegetical aspects of reception history, but just as ancient texts have contexts, 'receptors' of ancient texts have contexts as well, and this is what makes this project both challenging and stimulating. Let me illustrate this in just three ways from some work that I did recently on Psalm 137.

One obvious example is that in order to assess the later (Jewish) Greek translations and Aramaic paraphrases, or the later (Christian) Latin translations and even the Elizabethan English renderings of this Psalm, I have to gain some knowledge of the sound and sense of the psalm and to be aware of the problematic words or phrases in the Hebrew which lie at the base, directly or indirectly, of all translation. So this is why I personally think it is important to start with the Hebrew text. Secondly, I cannot fully understand the differences between later Jewish readings, which tend to read Psalm 137 as a complete 'poetic narrative', and later Christian readings, which are more predisposed to isolate and allegorize individual verses, unless I have some view myself about the overall structure of the psalm that each tradition is using; so again I need to have some understanding of the possible composition of the text in its earlier setting. Thirdly, I cannot appreciate the various receptions of Psalm 137 as a lament for a lost homeland, whether by Diaspora Jews in Persia or Greece or Rome or even thirteenth-century Italy, or by Christians suffering disenfranchisement in seventeenth- and eighteenth-century England and America, without coming to some view, however provisional, about whether its ancient setting is about the Babylonian exile or just after it, because this is what has consistently motivated these later imitations and commentaries. So, in my view, each new layer is part of an increasingly rich and complex discourse with the past. A sense of cultural history is vital; but in my view this begins with 'the beginning, assuming it might then inform some appreciation of how and why Jewish and Christian responses throughout that history diverge. This, then, is how I personally engage with the exegetical reception of the text at different stages in Jewish and Christian cultural history. It is, in part, a historical project. ${ }^{3}$

The second reason for accommodating reception history into the discipline of biblical studies is that it is reception history. This means it belongs as much to the more recent rhetorical and reader-response methods used in biblical studies as it does to the variety of more traditional historical methods referred to earlier. It has often been termed Wirkungsgeschichte; the history of the influence or the impact of

2 I shall say something later about how this relates to the 'History of Interpretation', although it should be clear that I see a close relationship between the two disciplines. As for the historical bias in this discipline, Christopher Rowland makes a good point when he argues (of the Blackwell Bible Commentary Series) that '... the historical-critical exegesis is included as part of Wirkungsgeschichte rather than as a primary datum to which matters of Wirkungsgeschichte can be added' (See http:// bbibcomm.net/files/rowland2004.pdf, p. 1).

3 See Susan Gillingham, 'The Reception of Psalm 137 in Jewish and Christian Traditions', in Susan Gillingham (ed.), Conflict and Convergence. Proceedings of the Oxford Conference on Jewish and Christian Approaches to the Psalms (Oxford: OUP, 2012). 
a text, acknowledging that the way a text is received and interpreted in a later period will probably be very different from the way it was received in its earlier context. Think, for example, of the way in which the psalms are so easily read by Christians as prayers or prophecies of Jesus Christ; what David Frost, in translating the Psalms in the mid-1960s, has rather graphically called 'pious fibs. ${ }^{4}$ So although its perspective is historical, its way of reading takes for granted that the meaning of the text is something brought to it through the responses of later readers in different cultural contexts. Sometimes this might mean not so much a bland acceptance of an earlier meaning, but a resistance to it, offering appropriate criticism of that earlier meaning in the light of its impact at a later stage in the process.

However, although reception history finds its metier alongside many of these more recent approaches, it again has a much broader purview. I offer just one example. Reception history is not only about the text as given and interpreted in words, but it is also about its reception of the text beyond the medium of words, especially, where the Psalms are concerned, in visual art, in liturgical enactment and in musical performance. But it is always the text - in my case, a particular psalm - which is at the centre of both the verbal and non-verbal reception; when the text itself disappears from sight and we realize we working more on the reception of the interpreters than the reception of the text, in my view, something has begun to go awry.

Again let me use Psalm 137 as an example of this, for I would argue that there are several different ways in which one can 'see' and 'hear' this psalm. The first is, quite simply, looking at and listening to the language and structure of the text in its most literal sense, as a corpus of words. The words may be in Hebrew, or Greek, or Latin, or Aramaic: but they are words, imitating and representing the words they are translating or paraphrasing, subtly shifting and changing the meanings throughout the passage of time. These may also be words created through the Hebrew poetry of disenfranchised paytanim, or words in many European languages in the laments of Holocaust survivors, or they may be words of metrical psalms, or imitations of psalms composed by political dissidents, both Catholic and Protestant, in sixteenth-century England: in each of these examples the shifts and changes in the meaning of this psalm are much more clear. At this more literary level we have to learn to be 'good readers', asking why this word or phrase has been emphasized and not another, why this poetic rhythm has been chosen and not another, and so on.

However, 'seeing' and 'hearing' pertains to more than just the transference of Psalm 137 from one verbal medium into another. It also involves, for example, 'seeing' through visual reception, and 'hearing' through musical reception. If I want to appreciate Psalm 137 visually - for example in the sketchy brown line drawings

4 See David Frost, Making the Liturgical Psalter. The Morpeth Lectures 1980 (Bramcote, Notts: Grove Books, 1981), pp. 10-25. 
in the ninth-century Utrecht Psalter, or in the starker contemporary black and white images in the art forms of Arthur Wragg, or in the more subtle representations of Roger Wagner or Michael Jessing - I have to learn how to 'look' and 'see' and 'perceive' how the text works beyond the medium of words alone. Similarly, if I want to understand the iconography of Psalm 137 in the Jewish Parma Psalter where the image of weeping carefully follows the Hebrew תורהנ and precedes, or observe it in the great wall mosaic in the Knesset by Marc Chagall, I again have to learn how to 'look' and 'see' and 'perceive' how the text works beyond the medium of words alone. And if I want to appreciate Psalm 137 in Philip de Monte's 'Super flumine Babylonis' or William Byrd's response in 'Quomode cantabimus' from Elizabethan England, or in Giuseppe Verdi's Nabucco in nineteenth-century Italy, I have to learn how to 'listen' and 'hear' and 'understand'. Similarly if I want to appreciate the psalm in the seventeenth-century Jewish melismatic chanting by Salomone Rossi of Mantua, or in the protest songs of the Rastafarians popularized by Boney Em and the Melodians and Sinead O'Connor, I have again to learn how to 'listen' and 'hear' and 'understand', and each time this is very different from how I would respond when using textual exegesis. ${ }^{5}$ Reception history allows us to engage with the text, but at many different and often unexpected levels.

So although reception history studies might sometimes sit uncomfortably in the domain of biblical studies, especially when the latter is defined predominantly by particular historical and literary concerns, this, I contend, is its home base. Its presence is, at times, uncomfortable for the status quo; it challenges historical critical methods when they are too exclusively focussed on just the ancient meaning, and it asks equally awkward questions of more recent 'readerly' methods when they are too confined by the words of the text and its subsequent literary impact as the only resource for meaning. ${ }^{6}$

\section{Responding to the critics}

Nevertheless, there have been some quite reasonable criticisms of reception history as a legitimate way of assessing the biblical text. I shall look at just four of them.

One of the most insistent criticisms is that reception history lacks any real theoretical theological underpinning. There have been two ways of responding to this. One is found in works which have sought to provide just this, at least in an introductory way: John Sawyer's account on the Blackwell Bible Commentary

5 See Susan Gillingham, 'Seeing and Hearing Psalm 137' in Kristinn Ólason, et al (eds), Mótun menningar. Shaping Culture. FS Gunnlaugur A. Jónsson (Reykjavík: Hið íslenska Bókmenntafélag 2012), pp. 91-108.

6 This account is not different from the way in which Christopher Rowland defends the significance of reception history, although his perspective is longer, reaching back to the Enlightenment, and he argues for the right balance between properly understood 'diachronic' and 'synchronic' approaches (C. Rowland in http://bbibcomm.net/files/rowland2004.pdf p. 3). 
website and Jonathan Roberts' introductory chapter in The Oxford Handbook of the Reception History of the Bible are cases in point. Sawyer traces the terminology of Rezeptionsaesthetik back to the Konstanz School of literary studies in the 1960s, developed by Hans Robert Jauss in his work on the relationship between the aesthetics of reception and Wirkungsgeschichte; Jauss's work on the multiple meanings resonant in the one text has some correspondences, Sawyer argues, with the work of Stanley Fish in the 1980s. ${ }^{7}$ Roberts takes a similar line: he traces the foundations of the discipline to the philosophical hermeneutics of Jauss's Doktorvater, Hans-Georg Gadamer, particularly in his model of the dialogical relationship between the past and the present, and argues that the first publications applying this to biblical studies emerge in Germany by New Testament scholars such as Ulrich Luz in the 1960s. ${ }^{8}$

A related but more measured response to this criticism is to state that it is too premature to synthesize the results of such a vast and burgeoning discipline; as Christopher Rowland has argued, it still needs more time to develop before any further hermeneutical models can be discussed with confidence. . I would argue that this view still holds (it dates from 2004). For example, the hermeneutical models proposed by Gadamer and Luz do not take into sufficient account the need to assess both Christian and Jewish receptions of the text, a task which is essential for anyone working on the Psalms. This more cautious approach is not unique. I can think of several other disciplines within biblical studies which also have not accounted for their presence in an explicit way, and, perhaps worse, disciplines where the discourse is so convoluted it is difficult to find a way out the maze. So even if the criticism of reception history for not yet creating its own rationale is legitimate, it is unfair to accuse it of this failure exceptionally and at this point in time. More reflection is required to explain better the origins and purpose of this discipline. What I believe is happening at present within this relatively new mode of study is that its focus is more on the 'how', in terms of consolidating its methods and reflecting on the purpose of its methods, and so at this point in time is less on the 'why'. It is in many ways still a pragmatic discipline, assessing the performative nature and the practical impact of biblical texts: at least, this is my own perspective, from working on the reception history of the Psalms. Reflections on good practice

7 See John Sawyer in http://bbibcomm.net/files/sawyer2004.pdf, pp. 1-2, referring to Hans Robert Jauss's Towards an Aesthetic of Reception (trans T. Bahti Minneapolis: University of Minnesota 1982), and the seminal work by Stanley E. Fish, Is There a Text in this Class? The Authority of Interpretive Communities (Harvard: Harvard University Press, 1980).

8 See Jonathan Roberts, 'Introduction' in Michael Lieb et al (eds), The Oxford Handbook of the Reception History of the Bible (Oxford: Oxford University Press, 2011), pp. 1-8. The same point is made by Mary Chiltern Callaway in her 'What's the Use of Reception History?' See http://bbibcomm. net/files/callaway2004.pdf, pp. 2-5.

9 See Christopher Rowland: 'The task of Wirkungsgeschichte at the present juncture requires, I think, that we refuse to move too quickly to hermeneutical models or theological syntheses. I'm really worried that we shall short-circuit the historical mapping exercise of the history of interpretation otherwise.' (http://bbibcomm.net/files/rowland2004.pdf p. 4). 
have begun, and others are bound to follow, and criticisms on bad practice will undoubtedly continue to be offered by those from outside. ${ }^{10}$ But the theoretical underpinning is part of a process; it will happen, and is happening, but coherence in a relatively new discipline, and reflections on that coherence, takes time to evolve. ${ }^{11}$ But in my view this is one of the most important challenges reception history has to face.

A second criticism in some ways is related to the first and is perhaps more serious because it is in part redeemable. This censures the discipline because of its tendency to be too descriptive. I can certainly understand how this happens. Usually one needs to draw together such a vast amount of data, often over a long period of time, so that by the end of the process - which usually results in collating together multiple responses to one single text - one is apt to lose sight of any clear hermeneutical key. There are many examples in print of what might be termed 'anthology without a purpose'. Usually one wants to ask after reading or hearing such papers, 'So what?' I would argue that if the exercize is little other than the assembling of information, one should probably avoid publishing it.

Yet, I contend, this somewhat 'flat' descriptive approach can be minimized by applying more focus, both in method and purpose. This is particularly possible in works which start with the text (in my case a psalm, and usually a short one at that) and work forwards, chronologically, in tracing some of its reception history. Initially one can gain a better focus by concentrating on just a few commentators and a defined period of history, where it is then possible to look more analytically at, for example, different Jewish and Christian modes of reception. A similar focus can be achieved by looking at one specific medium again over a prescribed period of time, perhaps with reference to ninth- and tenth-century illuminated manuscripts, or to sixteenth-century music for the royal court, or through contemporary music or film, to offer but three examples. Several publications, going back as far as the early 1990s, show the increased interest in reception history, and these include many examples in art, literature, music and film. ${ }^{12}$

10 For example, Roland Boer (http://bbibcomm.net/).

11 Roberts for example points to the 'multiplicity and diversity' of the papers in The Oxford Handbook of the Reception History of the Bible:'... the material is hermeneutically stimulating precisely because it will not coalesce. The more history of reception of the Bible one reads, the clearer it becomes that the human importance of the Bible does not lie in a single foundational meaning that, by dint of scholarly effort, may finally be revealed.' (p. 8).

12 See for example Paul Morris and Deborah Sawyer (eds.) A Walk in the Garden. Biblical, Iconographical and Literary Images of Eden (Sheffield: JSOT Press, 1992); John F. A. Sawyer, The Fifth Gospel. Isaiah in the History of Christianity (Cambridge: Cambridge University Press, 1996); Margaret Stocker, Judith, Sexual Warrior: Women and Power in Western Culture (Yale: Yale University Press, 1998); Yvonne Sherwood, A Biblical Text and Its Afterlives: The Survival of Jonah in Western Culture (Cambridge: Cambridge University Press, 2000); Bernhard Lang, Joseph in Egypt: A Cultural Icon from Grotius to Goethe (New Haven: Yale University Press, 2009); Andrew Mein and Paul Joyce (eds.), After Ezekiel: Essays on the Reception of a Difficult Prophet (London and New York: T \& T Clark International, 2010); and John Byron, Cain and Abel in Text and Tradition: Jewish and Christian Interpretations of the First Sibling Rivalry (Leiden: Brill, 2011). 
Another way of achieving analysis rather than plain description could be to start the other way round, and critically assess how one or two individuals (or indeed, communities) have used one particular biblical text or a group of texts: for example, Cheryl Exum's work on the Bible in literature, music, art and film; Martin O'Kane and John Morgan-Guy's volume on biblical art in Wales; Chris Rowland's work on Blake and the Bible, especially the book of Job; Deborah Rooke's account of Handel's use of biblical texts in his Oratorio Libretti; Aaron Rosen on Marc Chagall's stained glass windows of the Psalms; and Bill Goodman's work on the use of different psalms by $\mathrm{U} 2 \cdot{ }^{13}$ Of those who work with a more pragmatic and social-political emphasis in Wirkungsgeschichte, Christopher Rowland's work is probably the best known. ${ }^{14}$ The purpose is to establish a dialogue between the text and, in this case, visual or musical modes of reception; in my view, the problem of being overdescriptive only takes over when that dialogue dries up, for then all one hears is a description of the reception; the issue of the impact of the text is lost, and this is an example not so much of biblical studies on holiday as on a quick sightseeing tour.

A third criticism is perhaps more justified. This concerns the 'particularity' and 'selectivity' of reception history studies, and hence the problem of subjectivity on the part of anyone working in this field. I certainly find that the more I work on reception history, the more I am aware that I am an interpreter 'frozen' in a particular time and place and culture. So my perception is that of a western, English, white, middle-aged woman who also happens to be an Anglican Lay Reader. So although up to the first millennium I try to keep my eye on Christian and Jewish traditions, not only in the West but also in the East, increasingly my focus has to move westwards, and then to Western Europe, and then to the Englishspeaking world. I produced a series of maps at the beginning of each chapter in my Psalms through the Centuries, and these illustrate, alas, the increasingly parochial vision of the project; starting with the ancient Near East and moving through the Mediterranean, gradually working up northern France, with an eye to Germany and Italy and Spain, and then, by the seventeenth century, other than a brief glance towards America, remaining increasingly fixed on 'Britain'. ${ }^{15}$ Reception history

13 For example, Cheryl Exum, Retellings: The Bible in Literature Music Art and Film (Leiden: Brill Academic Publishers 2007); Martin O'Kane and John Morgan-Guy (eds.), Biblical Art from Wales, (Sheffield: Sheffield Phoenix Press, 2010); Christopher Rowland, Blake and the Bible (New Haven: Yale University Press, 2011); Deborah Rooke Handel's Israelite Oratorio Libretti: Sacred Drama and Biblical Exegesis (Oxford: Oxford University Press, 2012); Aaron Rosen, 'True Lights. Seeing the Psalms through Chagall's Church Windows', in Susan Gillingham (ed.), Conflict and Convergence. Proceedings of the Oxford Conference on Jewish and Christian Approaches to the Psalms' (Oxford: OUP, 2013); Bill Goodman, Relegere 2/1 (2012) (http://www.relegere.org/index.php/relegere/article/ view/483). A number of other examples (including John Hedley Brooke on Samuel Wilberforce and Thomas Huxley and Genesis, Emma Mason on William Blake's Illustrations of Job, Jeremy Holtom on Gandhi's use of the Sermon on the Mount) can be found in The Oxford Handbook of the Reception History of the Bible, pp. 397-412, 460-75 and 542-56 respectively).

14 See for example Christopher Rowland and Jonathan Roberts, The Bible for Sinners. Interpretation in the Present Time (London: SPCK, 2008).

15 See Susan Gillingham, Psalms through the Centuries Volume One (Oxford: Wiley-Blackwell 2008), pp. $6,48,78,132,193,243$. 
may have a broad remit, but the paradox is that any one individual collating and interpreting the material has to make difficult choices as to what to use. The processing of the data thus requires making informed but nevertheless subjective choices about what to include and what to exclude. Yet this 'incarnational' aspect can be found, in different degrees, in most other fields of biblical studies as well; I think here of biblical archaeology, of social scientific analyses, of ancient Near Eastern comparative studies, and even of exegetical commentaries. So the problem is not exceptional: it is just that reception history, because of its breadth and scope, sometimes highlights this limitation particularly clearly. ${ }^{16}$ So, the problem of being 'subjective' is inescapable. Reception history, like all other disciplines within biblical studies, is constrained by culture, gender, race and personal history.

A fourth criticism levelled against reception history is its tendency towards isolated (and indeed sometimes eccentric) individualism. This is particularly pertinent when one is working in a relatively new area where there are fewer sympathetic and experienced colleagues. I know all too well how one person attempting to draw together many different issues of reception, often over a long period of time, can be a recipe for disaster. I think of a closely related discipline, 'history of interpretation' where sometimes these are publications by a team of experts and sometimes these are works by one individual. ${ }^{17}$ Take, for example, Magno Saebø's lengthy edited volumes, Hebrew Bible Old Testament. The History of Its Interpretation, or Alan Hauser and Duane Watson's shorter editions, A History of Biblical Interpretation, or the one volume Cambridge Companion to Biblical Interpretation, edited by John Barton; compare this with Graf Reventlow's singleauthored four-volume publication, Epochen der Bibelauslegung, translated into English between 2009 and 2010 as A History of Biblical Interpretation. ${ }^{18}$ It is true

16 This is the position taken by Mary Callaway in her 'What's the Use of Reception History?' (http:// bbibcomm.net/files/callaway2004.pdf, p. 9). Sawyer discusses this issue in a different way: noting that opponents of Reception History accuse the proponents of subjectivity, his defense for the discipline is in relation not so much to the scholar/interpreter as to the meaning found in a text. Following the argument of Fish, that a text does not exist until someone reads it, and that the text when read does not have one meaning but the many meanings brought to it (rather than arising from it) by readers of many different interpretive communities, Sawyer contends that both objective analysis and objective results are impossible goals (http://bbibcomm.net/files/sawyer2004.pdf, pp. 2-3).

17 Callaway, http://bbibcomm.net/files/callaway2004.pdf, pp. 13-14, notes that the differences between History of Interpretation and Reception History is that the former takes a more exegetical and theological approach, and the latter approaches the subject more anthropologically and sociologically with a different concern about the impact of the text within a period of cultural history. But the two disciplines are undoubtedly closely related.

18 See Magno Saebø (ed.) Hebrew Bible Old Testament. The History of Its Interpretation, I/1: Antiquity, (Göttingen, Vandenhoeck \& Ruprecht, 1996); I/2: The Middle Ages (Göttingen, Vandenhoeck \& Ruprecht, 2000); II: From the Renaissance to the Enlightenment (Göttingen, Vandenhoeck \& Ruprecht, 2008); Alan J. Hauser and Duane F. Watson (eds.) A History of Biblical Interpretation. Volume 1. The Ancient Period, (Grand Rapids, MI: William B. Eerdmans Publishing Company, 2003); Volume 2, The Medieval through Reformation Periods (Grand Rapids, MI: William B. Eerdmans Publishing Company, 2009); John Barton (ed.), The Cambridge Companion to Biblical Interpretation (Cambridge: CUP 1998); and Henning Graf Reventlow, Epochen der Bibelauslegung (Bände 1-4) (München: Verlag C. H. Beck oHG, 1990-2001), Trans. Leo G. Perdue and James O. Duke, History of Biblical Interpretation (4 Volumes) (Atlanta, GA: SBL 2009-10). 
that an edited work can result in a project lasting for many years, so that one loses a good deal of continuity, but such a work can also achieve the breadth and depth which one individual even as skilled and informed as Reventlow could never do; the individual is inevitably less able to achieve the depth and breadth of a multiauthored edited work. What applies in works on the 'History of Interpretation' also applies to publications on reception history; for example, although the de Gruyter project is ambitiously intending to publish some thirty volumes from 2009 to 2018 , publishing some three volumes a year, it is clearly going to be an exceptionally thorough job, with over thirty editors working in five different divisions. ${ }^{19}$ By contrast, the projects undertaken by writers contracted into the Wiley-Blackwell Bible Commentary Series are hampered by being a single- (or sometimes two-) authored work, and so the depth and breadth they can really achieve is limited. However, I would still argue that the benefit of working in this one-authored way is that it provides cohesion and continuity and consistency. ${ }^{20}$

\section{The importance of collaboration}

It may seem strange to end a response to these four criticisms on a rather negative note, for this could be represented as undermining everything which the WileyBlackwell Reception History Commentary Series is trying to do. But I have deliberately emphasized this at the end as I believe that this weakness can in fact be turned into a most significant advantage, namely, reception history's potential for collaboration.

Again I speak personally, but it seems that it is precisely out of this sort of individual isolation that one also recognizes the need for scholarly support and advice (and e-mail communication and the accessibility of so much Internet access now helps enormously to this end). Collaboration works at many different levels. First, it can involve graduate research assistants who can retrieve material, collate the data electronically and produce a viable database; I find I now can turn to any one psalm and retrieve an enormous amount of material, both online and in filed hard copies, most of which has been assembled not by me but by those who have worked for me, some of them over a long period of time. ${ }^{21}$ Secondly, collaboration also includes turning to the many resources found within the wider academic

19 See http://www.degruyter.com/ebr for details of the extent of this project.

20 The details of the series can be found on http://bbibcomm.net and http://www.blackwellpublishing. $\mathrm{com} /$ seriesbyseries.asp?ref=BC and, focusing on the Old Testament, include publications by David G. Gunn, Judges through the Centuries (2004); Eric S. Christianson, Ecclesiastes through the Centuries (2006); and Jo Carruthers, Esther through the Centuries (2007). As well as the Wiley-Blackwell Commentary Series, John F.A. Sawyer's A Concise Dictionary of the Bible and its Reception (Louisville, KE: Westminster John Knox Press, 2009) is a commendable example of a 'one-person' achievement in and is arguably the first ever dictionary on Reception History.

${ }^{21}$ I am particularly indebted to Holly Morse in this respect. 
community. I offer just one example. I am completing at the moment a monograph on the reception history of Psalms 1, 2 and 1-2, which ranges from the Second Temple Period up to the present day, and which looks at both Jewish and Christian receptions of these psalms, separately and together; I first compare and contrast different types and results of exegesis, then assess the different liturgical innovations, and manuscript illuminations, and literary imitations, and musical compositions, and finally modern translations and contemporary artistic representations.

Setting aside the obvious need to be selective and to apply clear methods and always to keep the text in view, there is no way I can presume competence in every medium and certainly not through every historical period. So when I am concerned about whether I have understood properly the use of Psalm 1 (and possibly Psalm 2) in 4QFlorigelium at Qumran, I can ask (and have asked!) George Brooke in Manchester, or Peter Flint in Toronto, or Michael Wolter in Bonn. And when it comes to issues of the Septuagint translation, or New Testament readings (where Psalm 1 actually never appears but where Psalm 2 is frequently used) or the Church Fathers, or Medieval or Reformation Commentators, there are many colleagues in the wider 'academy' to whom I can now turn for help. Similarly when it comes to writing about Christian illuminated manuscripts, or medieval Jewish exegesis, or the liturgical or political or musical use of these psalms, there are now several different colleagues to whom I dare turn for advice about pursuing resources and understanding them as well as I can. Sometimes it seems like a great jigsaw puzzle, with individuals helping to place the smaller (and larger) pieces along on a very large table, with my job being to try to assemble it into a coherent, albeit multifaceted whole.

There is another way in which collaboration can be made effective. This is by way of brief, perhaps two-day, conferences where several papers are presented on the reception of just one biblical text or one biblical character or theme through a multiple number of media over a lengthy period of history. If these can be turned around into a publication of conference papers within, say eighteen months, this is a vital way of demonstrating how a more corporate form of collaboration works. One seminal example is a conference on the Jewish and Christian reception of the Psalms by Harold Attridge and Margaret Fassler, at Yale, some ten years ago.22 Another, on the reception of the Decalogue, was organized by Dominik Markl and took place in Oxford at Trinity College, Oxford, from 16 April to 18 April 2012: this was a multi-faceted project which still had a clear focus, and it is in the process of being turned into an edited work. ${ }^{23}$

22 H. W. Attridge and M. E. Fassler, Psalms in Community: Jewish and Christian Textual, Liturgical and Artistic Traditions (Atlanta: SBL 2003).

23 Another outlet is of course the Society for Biblical Literature international meetings. And yet another way is the publication of material in journals and periodicals: on this count, the new reception history journal, Biblical Reception, edited by Cheryl Exum and David Clines, is most welcome. It covers art, literature, film, popular culture, as well as the history of interpretation; the first edition is due in November 2012. 
Reception history also offers a model of collaboration between the academic community and other communities which have a different remit. To the outsider, biblical studies in the academy can sometimes seem to be an introverted discipline, and if it is to be respected in the outside world it needs to find as many ways as possible of crossing that divide. My own experience - and I do not think this is simply because I work on the Psalms - is that reception history offers a 'bridge' between academic and confessing communities, perhaps on diocesan retreats or parish days away. There are similar opportunities for fostering dialogue between Christian and Jewish aspects of reception of various biblical texts, perhaps through the Council of Christian and Jews or debates in local synagogues or at conferences held by The British Association for Jewish Studies. I am less adept than many at doing this, but if reception history is about the impact and the influence and the performance of biblical texts in all aspects of human history, then this element seems to me a vital part of the collaborative process. So to my mind, collaboration within and outside the discipline is the greatest contribution studies in reception history can make to biblical studies. ${ }^{24}$

\section{Doing reception history critically}

I want to conclude with a reminder that we all do reception history in one way or another, whether it is by reading a text through the eyes of a nineteenth-century German commentator or trying to understand a text through the fieldwork of a biblical archaeologist. What has taken place over the last two decades is in part a way of expanding and making further sense of what we are doing whenever we receive the text through a third hand, and indeed, of making sense of what others have done before us. The key issue is that we have to be properly critical in what we do, and reception history must also rise to this challenge. I end therefore with a pertinent observation from John Barton in his The Nature of Biblical Criticism. Barton is discussing the 'plain sense meaning' of Psalm 84, noting that it has further layers and textures beyond its own literal meaning. He concludes:

The plain sense can well contain within itself possibilities for finding layers of meaning well beyond the literal, and biblical critics need no more be under a self-denying ordinance that would rule this out than are their colleagues in the

\footnotetext{
24 Taking a much wider framework of reference, it is also important to note the work which has been done comparing First World and Third World receptions of biblical texts: one seminal example would be The Global Bible Commentary (Nashville, TN: Abingdon Press, 2004), edited by Daniel M. Patte. This is a model of reception history 'in the present tense', showing how the diverse social and economic contexts of readers can expose both the oppressive and liberating dynamics of biblical texts, and thus illustrating how reception history must also be an active process as well as a receptive one, offering a critical analysis of biblical texts rather than a bland acceptance of them.
} 
study of other branches of literature. To acknowledge this is far from making biblical study a free-for-all... There is responsible criticism, and there is irresponsible criticism, and knowing the difference is part of the skill of the good critic. ${ }^{25}$

25 John Barton, The Nature of Biblical Criticism (Louisville, KY and London: Westminster John Knox Press, 2007), p. 116. 